\title{
PENGARUH KOMITMEN KARYAWAN DAN KOMUNIKASI TERHADAP PRESTASI KERJA KARYAWAN PADA KOPERASI CU MANDIRI UNIT DAERAH TEBING TINGGI
}

\author{
Sinar Ritonga \\ Universitas Katolik Santo Thomas Medan Jl. Setia Budi No. 479F, 20132, Indonesia \\ e-mail: sinarritonga58@gmail.com
}

\begin{abstract}
This study aims to test and analyze Employee Commitment and Communication to Employee Performance at Cooperative CU Mandiri Unit Areas Tebing Tinggi. The data was collected through interviews and questionnaires distributed to 67 employees at CU Mandiri Cooperative Unit of Tebing Tinggi District. Data analysis in this study using SPSS version 20.The technique used is the method of sampling and data testing techniques used in this study include the validity test and reliability test, the classical assumption test. Multiple linear regression analysis, and hypothesis test also conducted to test and prove hypothesis in research. From the result of partial testing ( $t$ test) shows tcount $(2,240>$ ttable $(1,669)$ and its significance level is $0,018<0,05$ proves that employee commitment have positive and significant effect to employee performance tcount $(6,706)>$ ttable $(1,669)$ and its significance level is $0.000<0.05$ proves that communication has a positive and significant effect on employee performance $F$ Test shows Fcount> Ftable is 46,209> 3,14 and its significance level $(0,000<0,05)$ proves that employee commitment and communications have a positive and significant influence simultaneously on employee performance. From result of discussion obtained by equation of doubled linear regression is $Y=6,763+$ $0,365 X 1+0,767 X 2+\varepsilon i$. Result of analysis indicate that employee commitment have positive effect to employee performance, and communication have positive effect to employee performance on CU Mandiri Cooperative Unit of Tebing Tinggi Region. Coefficient of determination equal to 0,591 mean $59,1 \%$ that variation of employee work performance can be explained by variation of employee commitment and communication equal to $59,1 \%$ rest 40,9\% explained by other variable not included in this research.
\end{abstract}

Keywords: Employee Commitment, Communication, Job Performance Employee

\section{PENDAHULUAN}

Sumber daya manusia memiliki peranan penting dalam setiap perusahaan. Oleh karena itu, sumber daya manusia perlu mendapat perhatian serius agar dapat dikelola dengan baik. Perusahaan membutuhkan adanya faktor sumber daya manusia yang berpotensial, baik pemimpin maupun karyawan pada pola tugas dan pengawasan yang merupakan penentu tercapainya tujuan perusahaan.

Komitmen karyawan merupakan kesediaan karyawan dalam melakukan pekerjaannya dengan tulus dan baik serta dapat dipertanggung jawabakan. Komitmen sangatlah penting untuk mengembangkan perusahaan tersebut. dan keinginan karyawan untuk mempertahankan prestasi kerja dengan berusaha bekerja keras untuk mencapai target realisasi. karyawan yang memiliki komitmen kerja, biasanya mempunyai Keinginan kuat untuk tetap bertahan sebagai anggota karyawan dan menjalankan tugasnya dengan lebih baik

Komunikasi, yaitu proses penyampaian pesan antara atasan dan bawahan dalam melakukan pekerjaan baik didalam perusahaan maupun diluar perusahaan. dimana dalam melakukan pekerjaan pasti diperlukannya sebuah komunikasi yang efektif baik antara atasan dengan karyawan. Dengan adanya komunikasi yang efektif, karyawan akan mudah untuk melaksanakan tugasnya masing-masing sesuai arahan pimpinan

Prestasi kerja karyawan merupakan hasil kerja yang dicapai seseorang karyawan dalam melaksanakan pekerjaan yang dibebankan kepadanya. Untuk mencapai prestasi kerja yang optimal, maka perusahaan harus mampu menciptakan kondisi yang dapat mendorong 
dan memungkinkan karyawan untuk mengembangkan dan meningkatkan kemampuan serta keterampilan yang dimiliki secara optimal.

Credit Union(CU) adalah salah satu koperasi simpan pinjam yang muncul

dan berkembang atas prakarsa masyarakat yang dikelola masyarakat. Credit Union berperan penting dalam mensejahterakan angota-anggotanya. Hal tersebut dapat dibuktikan dengan peningkatan pendapatan dan jumlah simpanan di Credit Union itu sendiri. Penggunaan kredit untuk kegiatan produktif akan menambah produksi (investasi) dan bertambahnya produksi akan peningkatan pendapatan, yang akan berdampak pada peningkatan tabungan. CU Mandiri adalah salah satu Credit Union terbesar di Pulau Sumatera yang berpusat di Kota Tebing Tinggi Propinsi Sumatera Utara.

Berdasarkan hasil wawancara dengan Human Resources Development (HRD) pada Koperasi CU Mandiri Tebing Tinggi diketahui bahwa pimpinan mereka ini sudah membuat peraturan kerja yang harus ditaati oleh semua karyawan yaitu mulai dari ketepatan masuk jam kerja, ketepatan dalam menyelesaikan tugas yang diberikan oleh pimpinan, dan menciptakan suasana kerja yang tertib dan nyaman. Penulis menemukan beberapa masalah yang berkaitan dengan komitmen karyawan dalam bekerja dan bagaimana cara berkomunikasi dengan baik, dimana sebagian karyawan masih ada beberapa yang keluar masuk dan tidak sungguh-sungguh dalam bekerja. Untuk dapat melihat gambaran data keluar masuk karyawan dari tahun 2014-2016 dapat dilihat pada tabel 1.1 dibawah ini.

Tabel 1 Data Keluar-Masuk Karyawan Koperasi CU Mandiri Tebing Tinggi Tahun 2014-2016

\begin{tabular}{|l|l|l|l|l|}
\hline Tahun & Jumlah Karyawan & Out & In & $\mathbf{( \% )}$ Out \\
\hline 2014 & 120 orang & 20 & 50 & $16 \%$ \\
\hline 2015 & 150 orang & 30 & 45 & $20 \%$ \\
\hline 2016 & 165 orang & 15 & 50 & $9 \%$ \\
\hline
\end{tabular}

Sumber :Koperasi Cu Mandiri Tebing Tinggi

Dari tabel 1. dapat dilihat dalam tiga tahun terakhir ini selalu ada karyawan yang keluar dari perusahaan, hal ini membuktikan bahwa keinginan untuk tetap bertahan sebagai anggota karyawan belum sepenuhnya dimiliki oleh semua karyawan.

Selanjutnya, disajikan prestasi kerja karyawan diukur dari target penjualan pada tahun 2014-2016 tidak mencapai target yang ditetapkan oleh perusahaan adapun target dan realisasi Koperasi CU Mandiri Unit Daerah Tebing Tinggi dapat dilihat dari prestasi kerja karyawan dalam 3 tahun terakhir dilihat pada tabel 1.2 dibawah ini.

Tabel 2 Persentase Pencapaian Jumlah Penjualan Bagi CU Mandiri Tebing Tinggi tahun 20142016

\begin{tabular}{|l|l|l|l|l|}
\hline Tahun & Jumlah Karyawan & Target (Penjualan) & Realisasi & Presentase (\%) \\
\hline 2014 & 120 orang & 175.859 .145 .765 & 165.002 .733 .951 & $94 \%$ \\
\hline 2015 & 150 orang & 197.118 .917 .137 & 158.967 .533 .831 & $80 \%$ \\
\hline 2016 & 165 orang & 146.265 .505 .323 & 121.827 .516 .486 & $83 \%$ \\
\hline
\end{tabular}

Sumber : CU Mandiri

Berdasarkan Tabel 2 di atas, diketahui bahwa target penjualan oleh perusahaan yang ditetapkan dalam tiga tahun (2014-2016) tidak tercapai dan naik turunnya tingkat fluktuasi karena prestasi kerja karyawan belum maksimal. disebabkan oleh kurangnya komitmen dalam komunikasi yang kurang efektif terhadap atasan dan bawahan.

Pemimpin CU Mandiri Tebing Tinggi memiliki perilaku dalam memegang teguh prinsip dalam menjalankan visi dan misi perusahan, Pemimpin memberikan arahan mengenai hal apa yang harus dilakukan dalam pencapaian tujuan perusahan. Memberikan motivasi 
supaya karyawan mempunyai semangat yang tinggi yaitu memberikan berupa, pemberian insentif, kenaikan golongan, memberikan bonus kalau perusahaan mendapatkan untung. Dan memberikan sangsi kepada karyawan yang melanggar peraturan.

Berdasarkan latar belakang tersebut, maka penulis tertarik untuk melakukan penelitian ini dengan judul : "Pengaruh Komitmen Karyawan dan Komunikasi terhadap Prestasi Kerja Pada Koperasi CU Mandiri Unit Daerah Tebing Tinggi."

\section{TINJAUAN PUSTAKA}

\section{A. Pengertian Komitmen Karyawan}

Pengertian komitmen karyawan menurut Steers dalam Kuntjoro (2002) adalah rasa identifikasi, keterlibatan dan loyalitas seseorang yang dinyatakan oleh seorang pegawai terhadap organisasinya. Komitmen karyawan merupakan kondsi dimana pegawai sangat tertarik terhadap tujuan, nilai-nilai, dan sasaran organisasinya.

Menurut Meyer, (dalam Tjun Han 2012: 78), faktor-faktor yang mempengaruhi komitmen afektif seseorang antara lain yaitu:

1. Umur. Hubungan antara umur dan kemampuan kerja menjadi persoalan-persoalan yang kian penting selama dasawarsa terakhir. Setidaknya ada tiga alasan. Pertama, berkembang luas kepercayan bahwa kemampuan kerja akan berkurang sejalan dengan bertambahnya usia. Kedua, bahwa realitas kekuatan kerja sesuai dengan usia.

2. Gender. Sebagian orang mengatakan adanya perbedaan penting antara laki-laki dengan perempuan yang dapat mempenagruhi performasikerja yaitu: kemampuan memecahkan maslah, keterampilan menganalisis, motivasi, keramahan (suka bergaul), dorongan kompetisi, dan kemampuan belajar. Namun kenyataannya perbedaan tersebut tidak konsisten.

3. Masa Kerja. Hubungan masa kerja dengan dengan produktivitas seseorang yang mempunyai masa kerja lebih lama tidak selamanya lebih produktif bila dibandingkan pekerja baru. Hubungan masa kerjadengan absensi berbanding lurus, maksudnya adalah seseorang yang lebih senior cenderung lebih banyak absensi dibandingkan yunior.

\section{B. Indikator Komitmen Karyawan}

Indikator yang mempengaruhi tingkat komitmen karyawan dalam suatu organisasi. menurut Mowday et al (2001:165) indikator-indikator prilaku komitmen yang dapat dilihat pada karyawan adalah :

1. Keinginan kuat tetap sebagai anggota

Karyawan bangga bekerja di perusahaan, dan menganggap perusahaan sebagai tempat yang baik untuk bekerja.

2. Keinginan berusaha keras dalam bekerja

Adanya perasaan nyaman yang dirasakan karyawan membuat karyawan termotivasi untuk selalu berprestasi lebih baik lagi.

3. Penerimaan nilai organisasi.

Karyawan merasa bahwa nilai-nilai yang diterapkan dan berlaku di perusahaan sesuai dengan nilai yang dianut oleh karyawan.

4. Penerimaan tujuan organisasi.

Keinginannya untuk tetap berada di perusahaan membuat karyawan berusaha keras dalam melaksanakan tugas supaya tujuan perusahaan tercapai.

\section{Pengertian Komunikasi}

Menurut Effendy (2000:13) "Komunikasi adalah proses penyampaian pikiran atau perasaan oleh seseorang kepada orang lain dengan menggunakan lambang-lambang yang bermakna bagi kedua pihak, dalam situasi yang tertentu komunikasi menggunakan media 
tertentu untuk merubah sikap atau tingkah laku seorang atau sejumlah orang sehingga ada efek tertentu yang diharapkan.

Menurut Sofyandi (2005:130) komunikasi ada 2 (dua) yakni:

1. Komunikasi formal adalah komunikasi antara pengirimdan penerima berita mempunyai hubungan formal dalam organisasi.

Komunikasi formal ada 2 yakni:

a. Komunikasi Vertikal.

Komunikasi vertikal terdiri dari komunikasi ke atas dan ke bawah sesuai rantai perintah Komunikasi ke atas (Upward Communication) memiliki fungsi untuk mensuplai informasi kepada tingkatan manajemen atas tentang apa yang terjadi pada tingkatan bawah. Tipe komunikasi ini mencakup laporan-laporan periodik, penjelasan, gagasan dan permintaan untuk diberikan keputusan. Hal ini dapat dipandang sebagai data atau informasi umpan balik bagi manajemen atas.

Komunikasi ke bawah (Downward Communication) dimulai dari manajemen puncak kemudian mengalir ke bawah melalui tingkatan-tingkatan manajemen sampai ke karyawan lini dan personalia paling bawah. Maksud utama komunikasi ke bawah adalah untuk memberikan pengarahan, informasi, instruksi, nasehat/sasaran dan penilaian kepada bawahan serta memberikan informasi kepada para anggota organisasi tentang tujuan dan kebijaksanaan organisasi.

b. Komunikasi Horizontal. Komunikasi Horizontal meliputi hal-hal berikut ini :

1) Komunikasi diantara para anggota dalam kelompok kerja yang sama.

2) Komunikasi yang terjadi antara dan diantara departemen-departemen pada tingkatan organisasi yang sama.

Bentuk komunikasi ini pada dasarnya bersifat koordinatif, dan merupakan hasil dari konsep spesialisasi organisasi. Sehingga komunikasi ini dirancang untuk mempermudah koordinasi dan penanganan masalah. Komunikasi horizontal, selain membantu koordinasi kegiatan-kegiatan horizontal, komunikasi tipe ini juga menghindarkan prosedur pemecahan yang lambat.

2. Komunikasi informal

Komunikasi informal terjadi di antara karyáwan dalam suatu organisasi yang dapat berinteraksi secara bebas satu sama lain terlepas dari kewenangan dan fungsi jabatan mereka. Biasanya komunikasi informal dilakukan melalui tatap muka langsung dan pembicaraan lewat telepon. Komunikasi informal terjadi sebagai perwujudan dari keinginan manusia untuk bergaul (sosialisasi) dan keinginan untuk menyampaiakan informasi yang dipunyainya dan dianggap tidak dipunya oleh rekan kerjanya.

\section{Faktor-faktor yang mempengaruhi komunikasi}

Komunikasi sebagai suatu sistem hubungan yang dibentuk oleh sejumlah faktor. Adapun beberapa faktor yang mempengaruhi komunikasi adalah :

Menurut Mangkunegara (2004:148) ada dua faktor yang mempengaruhi komunikasi, yaitu faktor dari pihak sender atau disebut pula komunikator, dan faktor dari pihak receiver atau komunikan.

1. Faktor dari pihak sender atau komunikator, yaitu keterampilan, sikap, pengetahuan sender, media saluran yang digunakan.

a. Keterampilan Sender. Sender sebagai pengirim informasi, ide, berita, pesan perlu menguasai cara-cara penyampaian pikiran baik secara tertulis maupun lisan.

b. Sikap Sender. Sikap sender sangat berpengaruh pada receiver. Sender yang bersikap angkuh terhadap receiver dapat mengakibatkan informasi atau pesan yang diberikan menjadi ditolak oleh receiver.

c. Pengetahuan Sender. Sender yang mempunyai pengetahuan luas dan menguasai materi yang disampaikan akan dapat menginformasikan kepada receiver sejelas mungkin. 
d. Media Saluran yang Digunakan oleh Sender. Media atau saluran komunikasi sangat membantu dalam penyampaian ide, informasi atau pesan kepada receiver.

2. Faktor dari pihak receiver, yaitu keterampilan receiver, sikap receiver, pengetahuan receiver, dan media saluran komunikasi.

a. Keterampilan Receiver. Keterampilan receiver dalam mendengar dan membaca pesan sangat penting Pesan yang diberikan oleh sender akan dapat dimengerti dengan baik, jika receiver mempunyai keterampilan mendengar dan membaca.

b. Sikap receiver. Sikap receiver terhadap sender sangat mempengaruhi efektif tidaknya komunikasi. Misalnya, receiver bersikap apriori, meremehkan, berprasangka buruk terhadap sender, maka komunikasi menjadi tidak efektif, dan pesan menjadi tidak berarti bagi receiver.

c. Pengetahuan Receiver. Pengetahuan receiver sangat berpengaruh pula dalam komunikasi. Receiver yang mempunyai pengetahuan yang luas akan lebih mudah dalam menginterpretasikan ide atau pesan yang diterimanya dari sender.

d. Media saluran komunikasi. Media saluran komunikasi yang digunakan sangat berpengaruh dalam penerimaan ide atau pesan.

\section{E. Indikator Komunikasi}

Komunikasi adalah hubungan kontak antar manusia baik individu maupun kelompok. Dalam kehidupan sehari-hari di sadari atau tidak komunikasi adalah bagian dari kehidupan manusia itu sendiri. Manusia sejak dilahirkan sudah berkomunikasi dengan lingkungannya (Widjaja,2008:1).

Indikator yang digunakan dalam penelitian ini yaitu Menurut Effendy (2006:10) komunikasi meliputi lima indikator sehingga dapat dilaksanakan secara efektif, diantaranya:

1. Komunikator. Adalah seorang pencipta pesan sebagai suatu titik permulaan dan pengidentifikasian dalam kegiatan komunikasi.

2. Pesan Komunikasi. Proses komunikasi merupakan suatu informasi/isi pernyataan dalam bentuk bahasa, kode maupun lambang.

3. Media Komunikasi. Media adalah alat untuk sarana yang dipergunakan untuk menyampaikan proses dari komunikator Kepada komunikasi berupa surat, papan pengumuman, majalah, surat kabar dan sebagainya.

4. Komunikan. Komunikan adalah orang dituju, pihak penjawab atau penerima berita dari komunikator dengan berbagai tujuan.

5. Efek. Pemberi tanggapan atau dampak yang ditimbulkan oleh komunikasi dimana berasal dari komunikan.

\section{F. Pengertian Prestasi Kerja}

Menurut Hasibuan (2003:105) prestasi kerja adalah suatu hasil kerja yang dicapai seseorang dalam melakukan tugas-tugas yang dibebankan kepadanya yang didasarkan pada kecakapan, pengalaman, dan kesungguhan serta ketepatan waktu. Prestasi kerja dipengaruhi oleh tiga faktor yakni kemampuan dan minat seorang pekerja, kemampuan dan penerimaan atas penjelasan delegasi tugas dan peran, serta tingkat motivasi seorang pekerja.

Menurut Anoraga (2004:78), menyatakan faktor-faktor yang dapat mempengaruhi prestasi kerja karyawan adalah motivasi, disiplin kerja, pendidikan, keterampilan, lingkungan kerja dan sistem kerja, sikap etika kerja, gizi dan kesehatan, jaminan sosial, tingkat penghasilan, teknologi, sarana produksi, manajemen, dan kesempatan berprestasi.

Menurut Mangkunegara (2009:68) ada 2 faktor yang mempengaruhi pencapaian prestasi kerja yaitu:

1. Faktor Kemampuan. Secara psikologis, kemampuan karyawan terdiri dari kemampuan potensial (IQ) dan kemampuan reality (knowledge+skill). Artinya, karyawan yang memiliki IQ di atas rata-rata (110-120) dengan pendidikan yang memadai untuk jabatannya dan 
terampil dalam mengerjakan pekerjaan sehari-hari, maka ia akan lebih mudah mencapai kinerja yang diharapkan.

2. Faktor Motivasi. Motivasi terbentuk dari sikap seorang karyawan yang menghadapi situasi situasi kerja. Motivasi merupakan kondisi yang menggerakkan diri karyawan yang terarah untuk mencapai tujuan organisasi.Sikap mental merupakan kondisi mental yang mendorong diri karyawan untuk mencapai prestasi kerja secara maksimal.

\section{G. Indikator Prestasi Kerja}

Prestasi kerja adalah sebagai hasil kerja yang telah dicapai seseorang dari tingkah laku kerjanya dalam melaksanakan aktivitas kerja. Informasi tentang tinggi rendahnya prestasi kerja seorang karyawan tidak dapat diperoleh begitu saja tetap diperoleh melalui proses yang panjang yaitu melalui proses penilaian prestasi kerja. Dalam penilaian prestasi kerja ada beberapa indikator menurut ahli yakni :

Unsur-unsur yang dinilai oleh perusahaan sebagai indikator prestasi kerja adalah menurut Riani (2011:99) antara lain adalah:

1. Kualitas kerja. Yaitu kualitas kerja yang dicapai berdasarkan syarat-syarat kesesuaian dan kesiapannya.

2. Kuantitas kerja. Yaitu jumlah kerja yang dilakukan dalam suatu periode waktu yang ditentukan.

3. Inisiatif. Yaitu selaku aktif atau semangat menyelesaikan pekerjaan tampa menunggu perintah atasan artinya tidak pasif atau bekerja atas dorongan dari atasan.

4. Kerjasama. Yaitu kemampuan bergaul dan menyesuaikan diri serta kemampuan untuk memberi bantuan kepada karyawan lain dalam batas kewenangannya.

5. Pengetahuan. Luasnya pengetahuan seseorang mengenai pekerjaan dan keterampilan.

6. Kreativitas. Keaslian gagasan yang dimunculkan dan tindakan-tindakan menyelesaikan persoalan-persoalan yang timbul.

7. Dapat dipercaya. Kesadaran untuk dapat dipercaya.

\section{METODE PENELITIAN}

\section{A. Populasi dan Sampel}

Pada penelitian ini yang menjadi populasi adalah seluruh karyawan pada Koperasi CU Mandiri Unit Daerah Tebing Tinggi berjumlah 200 orang dengan perincian sebagai berikut:

Tabel 3. Populasi adalah seluruh karyawan

\begin{tabular}{|l|l|l|l|}
\hline No & Bagian & $\begin{array}{l}\text { Populasi } \\
\text { (orang) }\end{array}$ & Sampel (orang) \\
\hline 1 & Bagian Administrasi & 35 & $\begin{array}{l}=(35 / 200) \times 67=11,72 \\
\text { Dibulatkan menjadi } 12 \text { orang }\end{array}$ \\
\hline 2 & Bagian Personalia & 25 & $\begin{array}{l}=(25 / 200) \times 67=8,37 \\
\text { Dibulatkan menjadi } 8 \text { orang }\end{array}$ \\
\hline 3 & Bagian Keuangan & 25 & $\begin{array}{l}=(25 / 200) \times 67=8,37 \\
\text { Dibulatkan menjadi } 8 \text { orang }\end{array}$ \\
\hline 4 & Bagian Diklat & 35 & $\begin{array}{l}=(35 / 200) \times 67=11,72 \\
\text { Dibulatkan menjadi } 12 \text { orang }\end{array}$ \\
\hline 5 & Bagin IT & 35 & $\begin{array}{l}=(35 / 200) \times 67=11,72 \\
\text { Dibulatkan menjadi } 12 \text { orang } \\
=(45 / 200) \times 67=15,07 \\
\text { Dibulatkan menjadi } 15 \text { orang }\end{array}$ \\
\hline 6 & Bagian Marketing & 45 & $\mathbf{6 7}$ \\
\hline Jumlah & $\mathbf{2 0 0}$ &
\end{tabular}


Menurut Sugiyono, (2010) proportional random sampling adalah pengambilan anggota dari populasi dilakukan secara acak tanpa memperhatikan strata yang ada dalam populasi itu. Sampel yang diambil dihitung dengan menggunakan rumus Slovin yaitu :

$$
n=\frac{\mathrm{N}}{1+\mathrm{Ne}^{2}}
$$

Dimana $\quad \mathrm{n}=$ Jumlah sampel

$\mathrm{N}=$ Jumlah populasi

$\mathrm{e}^{2}=$ Presisi yang diharapkan $(10 \%)$

Berdasarkan rumus tersebut maka :

$$
\begin{aligned}
& n=\frac{\mathrm{N}}{1+\mathrm{Ne}^{2}} \\
& n=\frac{200}{1+\left(200 \times 0,1^{2}\right)} \\
& n=\frac{200}{3} \\
& n=66,67 \text { dibulatkan } 67 \text { orang }
\end{aligned}
$$

\section{B. Teknik Pengumpulan Data}

Pada penelitian ini digunakan data primer melalui wawancara

\section{Metode Penelitian}

Uji Validitas dan Reabilitas

Menurut Sugiyono (2008:188), syarat minimum dianggap memenuhi syarat kalau nilai $r=0,30$ ". Jadi kalau nilai korelasi antara butir dengan skor total kurang dari 0,30 , maka butir dalam instrumen tersebut dinyatakan tidak valid.

Uji reliabilitas adalah menguji apakah hasil kuesioner dapat dipercaya atau tidak. Menurut Sugiyono (2008:185), "pengujian reliabilitas dengan internal consistency, dilakukan dengan cara mencoba instrumen sekali saja, kemudian dianalisis dengan teknik tertentu". Pengujian reliabilitas instrumen dilakukan dengan teknik belah dua dari Spearmen Brown. Kriteria suatu variabel dikatakan reliabel atau tidak, adalah:

$$
\begin{aligned}
& \propto \geq 0,50 \text { artinya instrumen reliabel. } \\
& \propto<0,50 \text { artinya instrumen tidak reliabel. }
\end{aligned}
$$

\section{Metode Analisis}

Teknik analisis yang digunakan adalah persamaan regresi linear berganda yang berguna untuk mengetahui pengaruh komitmen karyawan dan komunikasi terhadap prestasi kerja karyawan (Sugiyono, 2008:277), dengan rumus:

$$
\mathbf{Y}=\mathbf{a}+\mathrm{b}_{1} \mathbf{X}_{1}+\mathrm{b}_{2} \mathbf{X}_{2}+\mathrm{e}
$$

\section{E. Uji Hipotesis}

Uji hipotesis dilakukan dengan menggunakan uji $\mathrm{F}$ dan uji $\mathrm{t}$, dengan prosedur pengujian sebagai berikut:

a. Uji F untuk mengetahui pengaruh secara simultan (menyeluruh)

1. $\mathrm{H}_{0}: \beta_{1}=0$, artinya, komitmen karyawan dan komunikasi tidak berpengaruh positif dan signifikan secara simultan terhadap prestasi kerja karyawan pada pada koperasi CU Mandiri Unit Daerah Tebing Tinggi.

2. $\mathrm{H}_{0}: \beta_{1} \neq 0$, artinya, komitmen karyawan, dan komunikasi berpengaruh positif dan signifikan secara simultan terhadap prestasi kerja karyawan pada koperasi CU Mandiri Unit Daerah Tebing Tinggi.

3. Jumlah sampel 67 Orang Level of significan ( $\alpha)=5 \%$ (uji satu arah)

4. Uji statistik F Sugiyono (2008:257) : 


$$
F h=\frac{R^{2} / k}{\left(1-R^{2}\right) /(n-k-1)}
$$

Keterangan: $\mathrm{F}_{\mathrm{h}}=\mathrm{F}_{\text {hitung }}$

$\mathrm{k}=$ Jumlah variabel bebas

$\mathrm{R}=\mathrm{R}$ Square

$\mathrm{n}=$ Jumlah sampel

5. Kriteria keputusan:

Jika $\mathrm{F}_{\text {hitung }}>\mathrm{F}_{\text {tabel, }}$ maka $\mathrm{H}_{0}$ ditolak dan $\mathrm{H}_{1}$ diterima

Jika $\mathrm{F}_{\text {hitung }} \leq \mathrm{F}_{\text {tabel, }}$ maka $\mathrm{H}_{0}$ diterima dan $\mathrm{H}_{1}$ ditolak

6. Kesimpulan: Dapat disimpulkan apakah hipotesis diterima atau ditolak.

b. Uji Statistik $\mathbf{t}$ untuk mengetahui pengaruh secara parsial (satu per satu)

1. $\mathrm{H}_{0}: \beta_{1}=0$, artinya komitmen karyawan,dan komunikasi tidak berpengaruh positif dan signifikan secara parsial terhadap prestasi kerja karyawan pada koperasi CU Mandiri Unit Daerah Tebing Tinggi.

$\mathrm{H}_{0}: \beta_{1} \neq 0$ artinya komitmen karyawan dan komunikasi berpengaruh positif dan signifikan secara parsial terhadap prestasi kerja karyawan pada koperasi CU Mandiri Unit Daerah Tebing Tinggi.

2. Jumlah sampel 67 Orang Level of significan $(a)=5 \%$ (uji satu arah)

3. Uji statistik t Sugyono, (2013:112).

$$
t=\frac{b}{S b}
$$

Dimana: $\mathrm{t}=\mathrm{t}_{\text {hitung }}$

$\mathrm{b}=$ Koefisien regresi

$\mathrm{Sb}=$ Standar error of estimate

4. Kriteria keputusan:

Jika $-t_{\alpha / 2 ; n-2}<\mathrm{t}_{\text {hitung }}<t_{\alpha / 2 ; n-2}, \mathrm{H}_{0}$ diterima

Jika $-t_{\alpha / 2 ; n-2} \geq \mathrm{t}_{\text {hitung }} \geq t_{\alpha / 2 ; n-2}, \mathrm{H}_{0}$ ditolak

Pengujian dilakukan dengan menggunakan SPSS (Statistical Package for Social Sciences) versi 20.

\section{HASIL PENELITIAN DAN PEMBAHASAN}

\section{A. Hasil}

Berdasarkan teknik analisis yang digunakan dengan persamaan regresi linear berganda untuk melihat pengaruh variabel komitmen karyawan dan komunikasi terhadap prestasi kerja unit daerah tebing tinggi.

Tabel 4. Coefficientsa variabel komitmen karyawan dan komunikasi terhadap prestasi kerja Unit daerah tebing tinggi Coefficients ${ }^{a}$

\begin{tabular}{|ll|l|l|l|l|l|}
\hline \multirow{2}{*}{ Model } & \multicolumn{2}{|l|}{ Unstandardized Coefficients } & $\begin{array}{l}\text { Standardized } \\
\text { Coefficients }\end{array}$ & T & Sig. \\
\cline { 2 - 5 } & B & Std. Error & Beta & & \\
\hline \multirow{2}{*}{1} & (Constant) & 7.673 & 2.447 & & 3.136 & .003 \\
& KK & .365 & .151 & .226 & 2.420 & .018 \\
K & .767 & .114 & .627 & 6.706 & .000 \\
\hline
\end{tabular}

a. Dependent Variable: PK 
Berdasarkan tabel diatas, menunjukkan persamaan regresi : $Y=7,673+0,365+0,767+$ ei. Persamaan tersebut menunjukkan bahwa variabel komitmen karyawan dan komunikasi terhadap prestasi kerja karyawan berpengaruh positif. Hal ini dapat dilihat dari nilai koefisien regresi regresinya yang bertanda positif.

Tabel 4. ANOVA ${ }^{a}$

\begin{tabular}{|cl|l|l|l|l|l|}
\hline \multicolumn{2}{|l|}{ Model } & Sum of Squares & Df & Mean Square & F & Sig. \\
\hline \multirow{4}{*}{1} & Regression & 600.238 & 2 & 300.119 & 46.209 & $.000^{\mathrm{b}}$ \\
& Residual & 415.673 & 64 & 6.495 & & \\
& Total & 1015.910 & 66 & & & \\
\hline
\end{tabular}

a. Dependent Variable: PK

b. Predictors: (Constant), K, KK

Berdasarkan tabel 4, menunjukkan bahwa secara simultan pengaruh variabel komitmen karyawan dan variabel komunikasi berpengaruh positif dan signifikan secara simultan terhadap prestasi kerja karyawan pada koperasi cu mandiri unit daerah tebing tinggi, dengan nilai $\mathrm{F}$ hitung 46,209 > F tabel 3,14 .

Tabel 5. Model Summaryb

\begin{tabular}{|l|l|l|l|l|}
\hline Model & R & R Square & Adjusted R Square & Std. Error of the Estimate \\
\hline 1 & $.769 \mathrm{a}$ & .591 & .578 & 2.549 \\
\hline
\end{tabular}

a. Predictors: (Constant), K, KK

Berdasarkan tabel 5 diatas, diketahui nilai koefisien korelasi (R) sebesar 0,769. Artinya, komitmen karyawan dan komunikasi mempunyai hubungan yang kuat terhadap prestasi kerja karyawan pada Koperasi CU Mandiri Unit Daerah Tebing Tinggi. Nilai koefisien determinan (R Square) sebesar 0,591. Artinya, prestasi kerja dapat dijelaskan oleh komitmen karyawan dan komunikasi sebesar 59,1\%, sedangkan 40,9\% lagi dijelaskan oleh faktor lain, seperti kompensasi, jaminan sosial, fasilitas, dan faktor-faktor lainnya yang tidak dijelaskan dalam penelitian ini.

\section{B. Pembahasan}

1. Pengaruh Komitmen Karyawan Terhadap Prestasi Kerja pada Koperasi CU Mandiri Unit Daerah Tebing Tinggi

Dilihat dari koefisien regresinya diketahui bahwa thitung untuk variabel komitmen karyawan adalah 2,420 sedangkan nilai $t_{\text {tabel }}$ adalah sebesar 1,669 sehingga $2,420>1,669$. Selain itu untuk nilai signifikannya $(0,018<0,05)$ dengan memperhatikan nilai $t_{\text {tabel }}$ (satu arah) maka $\mathrm{H}_{\mathrm{a}}$ diterima dan $\mathrm{H}_{0}$ ditolak. Dengan ditolaknya $\mathrm{H}_{0}$ berarti komitmen karyawan berpengaruh positif dan signifikan terhadap prestasi kerja pada Koperasi CU Mandiri Unit Daerah Tebing Tinggi.

\section{Pengaruh Komunikasi Terhadap Prestasi Kerja Pada Koperasi CU Mandiri Unit Daerah Tebing Tinggi}

Dilihat dari koefisien regresinya diketahui bahwa $t_{\text {hitung }}$ untuk variabel komunikasi adalah 6,706 dengan tingkat signifikan 0,000 dengan nilai $t_{\text {tabel }}$ pada Alpha $5 \%$ dfl $=64$ adalah 1,669. Variabel komunikasi berpengaruh positif dan signifikan terhadap prestasi kerja pada Koperasi CU Mandiri Unit Daerah Tebing Tinggi terlihat dari nilai signifikan $0,000<0,05$ dan nilai $t_{\text {hitung }}(6,706)>t_{\text {tabel }}(1,669)$. 


\section{Pengaruh Komitmen Karyawan Dan Komunikasi Terhadap Prestasi Kerja Pada Koperasi CU Mandiri Unit Daerah Tebing Tinggi}

Dilihat dari koefisien regresinya diketahui bahwa secara simultan terdapat pengaruh positif dan signifikan antar variabel komitmen karyawan dan komunikasi terhadap variabel prestasi kerja. Pengaruh tersebut ditunjukkan pada nilai $F_{\text {hitung }}$ sebesar 46,209> $\mathrm{F}_{\text {tabelsebesar }}$ 3,14 sehingga dapat disimpulkan bahwa secara simultan variabel komitmen karyawan dan komunikasi mempengaruhi prestasi kerja pada Koperasi CU Mandiri Unit Daerah Tebing Tinggi.

\section{KESIMPULAN}

Berdasarkan hasil pembahasan, dapat disimpulkan bahwa:

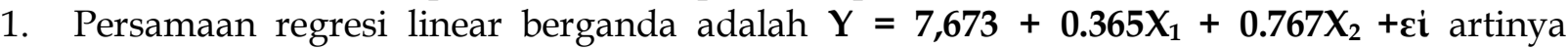
komitmen karyawan dan komunikasi berpengaruh positif terhadap prestasi kerja karyawan pada Koperasi CU Mandiri Unit Daerah Tebing Tinggi. Variabel yang berpengaruh paling dominan terhadap prestasi kerja karyawan adalah faktor komunikasi(X2), karena nilai koefisien korelasinya lebih besar daripada nilai faktor komitmen karyawan(X1)

2. Dilihat dari hasil uji $\mathrm{F}$, disimpulkan bahwa komitmen karyawan(X1), dan komunikasi(X2) berpengaruh positif dan signifikan secara simultan terhadap prestasi kerja $(Y)$ unit manager Koperasi CU Mandiri Unit Daerah Tebing Tinggi. Hal ini dapat dilihat dari uji $\mathrm{F}$ bahwa $F_{\text {hitung }}>F_{\text {tabel }}$ adalah sebesar 46,209 > 3,14 dan tingkat signifikannya $(0,000<0,05)$ dengan memperhatikan $\mathrm{F}_{\text {tabel }}$ (satu arah) maka $\mathrm{H}_{\mathrm{a}}$ diterima dan $\mathrm{H}_{0}$ ditolak.

3. Dilihat dari uji t disimpulkan bahwa, komitmen karyawan dan komunikasi secara parsial berpengaruh positif dan signifikan terhadap prestasi kerja karyawan pada Koperasi $\mathrm{Cu}$ Mandiri Unit Daerah Tebing Tinggi. Hal ini dapat dilihat dari uji $t$ bahwa variabel komitmen karyawan $\left(\mathrm{X}_{1}\right)$ nilai $\mathrm{t}_{\text {hitung }}>\mathrm{t}_{\text {tabel }}$ yakni2,240 $>1,669$ dan tingkat signifikansinya adalah sebesar $0,018<0,05$ dan variabel komunikasi $\left(X_{2}\right)$ nilai $t_{\text {hitung }}>t_{\text {tabel }}$ yakni $6,706>$ 1,669 dan tingkat signifikansinya adalah sebesar 0,000 <0,05.

4. Nilai koefisien korelasi (R) sebesar 0,769. Artinya, komitmen karyawan dan komunikasi mempunyai hubungan yang kuat terhadap prestasi kerja karyawan pada Koperasi CU Mandiri Unit Daerah Tebing Tinggi. Nilai koefisien determinan (R Square) sebesar 0,591. Artinya, prestasi kerja dapat dijelaskan oleh komitmen karyawan dan komunikasi sebesar $59,1 \%$ sedangkan 40,9\% lagi dijelaskan oleh faktor lain, seperti faktor kompensasi, jaminan sosial, dan fasilitas, dan faktor-faktor lainnya

\section{DAFTAR PUSTAKA}

Anoraga, Pandji. 2004. Manajemen Bisnis, Cetakan Ketiga, Rineka Cipta, Jakarta.

Arni, Muhammad. (2005). Komunikasi Organisasi. Jakarta: Bumi Aksara.

Arikunto S, 2006. Prosedur Penelitian Suatu Pendekatan Praktik, Ed Revisi VI, Penerbit PT Rineka Cipta, Jakarta.

Effendy, Onong. 2000. Ilmu Teori dan Filsafat Komunikasi. Bandung: $\quad$ PT.Rosdakarya.

Prestasi Kerja di PT. Kereta Api Indonesia (Persero) Sub. Divisi Regional III.2. Tanjung Karang, Bandar Lampung, karya ilmiah.polnes.ac.id.

Ghozali, 2005. Aplikasi Analisis Multivariate dengan program SPSS, Badan Penerbit Universitas Diponegoro, Semarang.

Handoko, T . Hani. (2001). Manajemen Personalia dan Sumber Daya Manusia Yogyakarta: BPFE Yogyakarta.

Hasibuan, Malayu S.P, 2003, Manajemen Sumber Daya Manusia, Edisi Revisi, Bumi Aksara, Jakarta 2011. Manajemen Sumber Daya Manusia. PT Bumi Aksara. Jakarta. 
Mangkunegara, Anwar Prabu (2002), Manajemen Sumber Daya Manusia, PT. Remaja Rosda Karya, Bandung.

Marzuki, 2005, Metodologi Riset, Yogyakarata: Ekonisia.

Purwanto, Djoko. 2003. Komunikasi Bisnis. Jakarta: Erlangga.

Riani, M. (2011). Perspektif Kompensasi. Surakarta: Yuma Pustaka.

Richard M. Steers dalam Kuntjoro 2002. Employee Training and Development, International Edition. McGraw -Hill.

Soekidjan. 2009. Manajamen Sumber Daya Manusia. Jakarta: BumiAksara.

Sopiah. (2008). Perilaku Organisasional. CV ANDY, Yogyakarta.

Sugiyono, (2008). Metode Penelitian Kunatitatif Kualitatif dan R\&D. Bandung Alfabeta. (2010). MetodePenelitian Kuantitatif Kualitatif \& RND. Bandung :

Alfabeta.

Sutrisno, Edi. 2009. Manajemen Sumber Daya Manusia Edisi pertama. Jakarta: Kencana Prenada Media Group.

Wibowo. 2012. Manajemen Kinerja (Edisi Ke 3). Jakarta: Rajawali Pers. 130.

Widjaja. 2008. Dasar-Dasar Customer Relationship Management (CRM). Jakarta: Harvindo.

Winarno, F.G. 2008. Kimia Pangan dan Gizi: Edisi Terbaru. Jakarta. Gramedia ～Pustaka Utama.. 